\title{
Extraction of leaf protein from green crops. Chemical composition and nutritive value of products of fractionation
}

\author{
MATTI NÄSI \\ Department of Animal Husbandry, University of Helsinki, SF-00710 Hel- \\ sinki 71
}

\begin{abstract}
Leaf protein was extracted from different green crops in 11 pilot plant esperiments. Of the crops, 4 were grass, 6 clover and one pea. The extraction of juice was on average $55 \%$ of the fresh weight of the green crop and the values for dry matter (DM) and crude protein $(\mathrm{CP})$ were 22.6 and $24.1 \%$. Clover gave better recoveries of protein than grass. In the leaf protein concentrate (LPC) obtained from the juice, the separation ratios for DM, CP and TP (true protein) were, respectively, $23.7 \%, 48.0$ and 80.7 $\%$. Heating to $85^{\circ} \mathrm{C}$ gave more efficient recoveries of LPC than the combination of heating and acid precipitation. The average DM content of the pressed pulp was $30.4 \%$, the corresponding value for the whole crop being $16.5 \%$. Measured on a DM basis, the CP content of the pressed pulp was only $0.4 \%$ units lower than in untreated forage, but the crude fibre content was $7.3 \%$ units higher. In vitro organic matter digestibility and the pepsin- $\mathrm{HCl}$ solubility of crude protein were on average 5.1 and $5.5 \%$ units lower in the pulp. The average DM of the plant juice was $6.5 \%$ and contained $21.9 \%$ ash, $21.5 \% \mathrm{CP}$, $10.7 \%$ TP and $29.9 \%$ soluble sugars. Clover and pea had much higher values for CP and TP than grass. In the LPC preparations, CP and TP averaged $43.6 \%$ and $38.5 \%$ of DM. Heat treatment gave higher protein content than precipitation of LPC by combined heating and acidification. The in vitro digestibility and protein solubility of LPC were high, on average $85.6 \%$ and $80.2 \%$. LPC had fairly high contents of lysine and methionine, $4.1 \%$ and $1.6 \mathrm{~g} / 16 \mathrm{~g} \mathrm{~N}$. There were only small differences in the amino acid composition between grass and clover and between crops harvested at different growth stages.

Green crop fractionation is a potential means of improving grassland production and utilization. Promising results have been obtained with plant juice and LPC fed to monogastric animals and pressed pulp residues in diets for ruminants. The economic aspects of fractionation remain to be evaluated.
\end{abstract}

\section{Introduction}

Green crops can be separated by mechanical methods into two fractions, protein-rich plant juice for monogastric animals and fibrous pressed pulp for ruminants. Further processing of the green juice gives leaf protein concentrate (LPC) and deproteinized juice (WILKINS 1977, PIRIE 1978). In Finnish conditions pasture swards, both grass and legumes, have remarkably high dry matter (DM) and protein yields right up to northern Finland. By making grass silage at an early stage of growth, protein requirements of ruminants 
can be satistied. The supplementary protein for non-ruminants and highly productive ruminants is mostly imported. The use of leaf protein from grass and legumes could be a way to increase the country's self-sufficiency in respect of protein. The concentration of protein in grass and legumes that have been fertilized properly and harvested at an immature growth stage is greater than that required by most ruminants. The losses during ensiling of fresh grass cut at an early growth stage are considerable (NØRRGAARD PEDERSEN et al. 1980); ETTALA and KOSSILA (1980) found that the total weight losses averaged $31.9 \%$ and those for DM and CP 21.2 . \% and $19.5 \%$. The effluent losses are most important when the silage crops have a low DM content. When peas and horse beans were ensiled, the effluent losses amounted to over $30 \%$ of the weight of the crop and the DM and CP losses in the effluent were $15 \%$ of the values of the original crop (SYRJÄLÄ et al. 1980, SYRJÄLÄ-QVIST et al. 1982). By fractionating the crop, effluent losses could be avoided and grassland production and utilization could be increased.

The objective of the investigation reported here was to perform leaf protein extraction on various pasture crops in Finnish conditions, to examine the chemical composition of the products of fractionation, and to asses their nutritive value and suitability for animal feeding. The results of a study of the preservation of plant juice and wet leaf protein concentrate are published in another report (NÄSI 1983).

\section{Materials and methods}

Eleven different crops were fractionated during summers 1979 and 1980: four grass crops, six clover and one pea. Table 1 shows the cutting dates, crop production, and yields of dry matter (DM) and crude protein $(\mathrm{CP})$ per hectare. The leys of grass mix (timothy $40 \%$, meadow fescue $40 \%$ and red clover $20 \%$ ) and pure stands of red clover were second or third years' growth. The crops were first cuts, except grass 2, which was a second cut. The fertilizer application per ha on the grass swards was N $190 \mathrm{~kg}, \mathrm{P} 15 \mathrm{~kg}$ and $\mathrm{K} 30 \mathrm{~kg}$ and on the clover N $16 \mathrm{~kg}, \mathrm{P} 50 \mathrm{~kg}$ and $\mathrm{K} 95 \mathrm{~kg}$; for the pea crop it was $\mathrm{N} 70 \mathrm{~kg}, \mathrm{P} 35 \mathrm{~kg}$ and $\mathrm{K} 35 \mathrm{~kg}$. The grass leys and peas were harvested with a chopper and the clover was cut with an experimental harvester.

The green crops were pulped with a laboratory cutter to rupture the plant cells, after which juice was expressed hydraulically (HAF press $0.75 \mathrm{~kW}$, pressure $200 \mathrm{kN}$ ). The leaf protein was coagulated by heating the juice to $85^{\circ} \mathrm{C}$ with steam injection, or precipitated by combined heating and acidification with $0.5 \% \mathrm{v} / \mathrm{w}$ conc. $\mathrm{HCl}$. The precipitated leaf protein coagulum was separated by cloth filtration.

Samples for analysis were taken from the green crop before and immediately after pressing. These and samples of the juice and LPC were stored in the deep-freeze until analysed. Samples were vacuum-dried at $+50^{\circ} \mathrm{C}$. The $\mathrm{DM}$ determinations were made at $103^{\circ} \mathrm{C}$. The feed analyses were made by standard methods, water-soluble carbohydrate was determined by the 
Table 1. Outline of the experiment.

\begin{tabular}{clrcccc}
\hline $\begin{array}{c}\text { Trial } \\
\text { no }\end{array}$ & Crop & $\begin{array}{c}\text { Cutting } \\
\text { date }\end{array}$ & $\begin{array}{c}\text { Fresh yield, } \\
\text { tn/ha }\end{array}$ & $\begin{array}{c}\text { DM yield, } \\
\text { kg/ha }\end{array}$ & $\begin{array}{c}\text { Crude protein } \\
\text { yield, kg/ha }\end{array}$ & $\begin{array}{c}\text { Pressed, } \\
\text { kg }\end{array}$ \\
\hline 1 & Grass 1 & 12.6 .79 & 13.7 & 2900 & 440 & 150 \\
2 & Grass 2 & 23.7 .79 & 14.3 & 1800 & 340 & 683 \\
3 & Grass 3 & 4.6 .80 & 9.2 & 1750 & 400 & 285 \\
4 & Grass 4 & 10.6 .80 & 9.5 & 1750 & 410 & 279 \\
5 & Clover 1 & 20.6 .79 & 9.7 & 2950 & 600 & 270 \\
6 & Clover 2 & 25.6 .79 & 15.9 & 2950 & 480 & 508 \\
7 & Clover 3 & 16.6 .80 & 15.8 & 2500 & 540 & 370 \\
8 & Clover 4 & 18.6 .80 & 16.9 & 2450 & 495 & 294 \\
9 & Clover 5 & 23.6 .80 & 22.8 & 3700 & 660 & 332 \\
10 & Clover 6 & 2.7 .80 & 26.5 & 4350 & 685 & 310 \\
11 & Pea & 16.7 .79 & 43.0 & 4350 & 850 & 502 \\
\hline
\end{tabular}

method of SALO (1965) and pepsin-HCl-soluble protein by digesting a $0.5-\mathrm{g}$ sample in $50 \mathrm{ml}$ of $0.1 \mathrm{~N} \mathrm{HCl}$ containing $0.1 \%$ pepsin for $20 \mathrm{~h}$ in $40^{\circ} \mathrm{C}$. In vitro digestibility was measured according to the method of TILLEY and TERRY (1963). Minerals were determined with a Varian Techtron 1000 A atomic absorption-spectrophotometer and phosphorus by the method of TAUSSKY and SHORR (1953). The amino acid composition was analysed with a gas chromatograph (Hewlett Packard 5830 A) by the method of NÄSI and HUIDA (1982).

\section{Results and discussion}

The extraction ratios of the plant juice and its components for the different crops are shown in Table 2. On average, $55 \%$ of the fresh weight of the green crop was expressed as juice and the extraction ratios for DM, and crude protein $(\mathrm{CP})$ were $22.6 \%$ and $24.1 \%$, respectively. The values were higher for clover than for grass; the $\mathrm{CP}$ extraction ratio was twice as high as in grass and the true protein (TP) ratio three times as high. The extraction ratio of water-soluble carbohydrates was very high, on average $75.9 \%$.

The extraction of juice and its components depends mainly on the crop species, stage of maturity at harvest and crop moisture content, but it is also affected by the mechanical treatment of the crop prior to pressing and the types of press used (HOUSEMAN and JONES 1978). The extraction of protein requires efficient maceration of the crop to rupture the cells before pressing. OSTROWSKI (1976) reports that the protein recover from grass ranges between 5 and $30 \%$, but it is possible to achieve protein recovery of between 40 and $50 \%$.

The leaf protein curd averaged $12.1 \%$ of the weight of the plant juice. The average separation ratios for DM, CP and TP were $23.7 \%, 48.0 \%$ and $80.7 \%$ (Table 3). Precipitation of LPC components was more efficient with clover juice than with grass. Protein (CP and TP) separation ratios were 
Table 2. Extraction ratios (\%) of plant juice and its components for various crops.

\begin{tabular}{|c|c|c|c|c|c|c|}
\hline Crop & Juice & DM & Ash & $\begin{array}{l}\text { Crude } \\
\text { protein }\end{array}$ & $\begin{array}{c}\text { True } \\
\text { protein }\end{array}$ & $\begin{array}{l}\text { Water soluble } \\
\text { carbohydrates }\end{array}$ \\
\hline Grass 2 & 54.7 & 17.6 & 48.9 & 18.1 & 12.5 & 88.2 \\
\hline Grass 3 & 42.3 & 15.2 & 37.9 & 12.4 & 4.7 & 43.5 \\
\hline Grass 4 & 49.6 & 14.2 & 38.9 & 14.2 & 4.6 & 60.6 \\
\hline Clover 1 & 60.6 & 27.3 & 50.3 & 23.4 & 20.3 & 93.3 \\
\hline Clover 2 & 60.6 & 26.0 & 52.0 & 24.7 & 17.6 & 91.2 \\
\hline Clover 3 & 58.2 & 27.5 & 48.9 & 27.5 & 21.2 & 74.6 \\
\hline Clover 4 & 61.7 & 28.8 & 51.4 & 32.1 & 22.6 & 86.4 \\
\hline Clover 5 & 60.4 & 28.1 & 51.6 & 33.8 & 25.6 & 76.5 \\
\hline Clover 6 & 59.3 & 24.9 & 50.9 & 28.0 & 19.3 & 71.9 \\
\hline Pea & 42.9 & 16.7 & 24.8 & 27.2 & 23.2 & 72.9 \\
\hline Overall mean & 55.0 & 22.6 & 45.6 & 24.1 & 17.2 & 75.9 \\
\hline Grass mean & 48.9 & 15.6 & 41.9 & 14.9 & 7.3 & 64.1 \\
\hline Clover mean & 60.1 & 27.1 & 50.0 & 28.3 & 21.1 & 82.3 \\
\hline
\end{tabular}

higher when protein was coagulated by heating than when it was precipitated by combined heating and acidification. The true protein recoveries were in some cases over one hundred per cent which indicates that some changes in the protein fraction had been caused by the heating treatment. Cloth filtration was not efficient enough; when the composition of the deproteinized juice (DPJ) was examined, $3.7 \%$ of the DM was found to be true protein (Table 7).

The chemical composition and in vitro digestibility of the forage and pulped pressed forage are compared in Table 4. The pulp which remains after juice has been expressed from the green crop contains almost all the fibre of the original crop and a proportion of the crude protein, soluble carbohydrates and mineral matter. The average dry matter content increased in processing from $16.5 \%$ to $30.4 \%$. The crude protein content, calculated on a dry matter basis, decreased by only $0.4 \%$ units, but crude fibre increased by $7.3 \%$ units. Pepsin- $\mathrm{HCl}$-soluble protein was $5.5 \%$ units lower and in vitro organic matter digestibility $5.1 \%$ unitserlower in the pressed pulp than in the crop prior to processing.

The enegy content in the original crop averaged $14.54 \mathrm{MJ} \mathrm{ME} / \mathrm{kg} \mathrm{DM}$ and in the pressed crop $13.70 \mathrm{MJ} \mathrm{ME} / \mathrm{kg} \mathrm{DM}$, calculated according to the equation presented by TERRY et. al. (1974). The corresponding NE values were $1.18 \mathrm{~kg} \mathrm{DM} / \mathrm{FU}$ and $1.25 \mathrm{~kg} \mathrm{DM} / \mathrm{FU}(1 \mathrm{FU}=0.7 \mathrm{~kg}$ starch). In the fractionation of green crops, large quantities of the more digestible nutrients are removed, leaving pulp containing larger relative amounts of cell wall material, and according to the chemical analysis the pressed pulp should have a lower nutritive value than the whole crop. But when the juice extraction is moderate as in the present experiment, where the juice DM averaged $22.6 \%$ of the DM in the whole crop, the nutritive value does not decrease too much. When the crop is cut at an early growth stage, the protein and energy values 
Table 3. Separation ratios of leaf protein precipitated from plant juice and its components as percentages.

\begin{tabular}{|c|c|c|c|c|c|}
\hline Juice and treatment & LPC & DM & Ash & $\begin{array}{l}\text { Crude } \\
\text { protein }\end{array}$ & $\begin{array}{c}\text { True } \\
\text { protein }\end{array}$ \\
\hline Grass 2 & 5.3 & 14.9 & 7.5 & 32.3 & 58.0 \\
\hline $\mathrm{HCl}$ prec. & 6.0 & 15.4 & 5.9 & 32.6 & 56.5 \\
\hline Grass 3 & 6.3 & 13.9 & 11.7 & 32.7 & 95.3 \\
\hline Grass 4 & 5.6 & 12.3 & 7.8 & 19.9 & 69.6 \\
\hline Clover 1 & 11.2 & 19.8 & 10.1 & 50.6 & 50.6 \\
\hline Clover 2 & 9.8 & 15.9 & 10.4 & 32.9 & 53.0 \\
\hline $\mathrm{HCl}$ prec. & 13.1 & 20.5 & 12.5 & 40.4 & 64.0 \\
\hline Clover 3 & 17.7 & 30.3 & 16.1 & 63.6 & 99.9 \\
\hline $\mathrm{HCl}$ prec. & 19.1 & 33.8 & 17.2 & 64.6 & 103.7 \\
\hline Clover 4 & 16.8 & 29.3 & 15.3 & 62.6 & 98.1 \\
\hline Clover 5 & 19.1 & 34.5 & 18.0 & 74.9 & 109.5 \\
\hline $\mathrm{HCl}$ prec. & 15.4 & 27.4 & 13.3 & 52.4 & 79.9 \\
\hline Clover 6 & 13.2 & 26.2 & 12.5 & 65.8 & 104.2 \\
\hline $\mathrm{HCl}$ prec. & 11.3 & 20.1 & 10.4 & 42.0 & 65.0 \\
\hline Pea & 15.1 & 41.1 & 25.1 & 65.7 & 118.6 \\
\hline $\mathrm{HCl}$ prec. & 8.0 & 24.4 & 20.6 & 34.8 & 65.2 \\
\hline Overall mean & 12.1 & 23.7 & 13.4 & 48.0 & 80.7 \\
\hline Grass mean & 5.8 & 14.1 & 8.2 & 29.4 & 69.9 \\
\hline Clover mean & 14.7 & 25.8 & 13.6 & 55.0 & 82.8 \\
\hline Heat precipitation & 12.0 & 23.8 & 13.5 & 50.1 & 85.7 \\
\hline Heat $+\mathrm{HCl}$ prec. & 12.2 & 23.6 & 13.3 & 44.5 & 72.4 \\
\hline
\end{tabular}

of pressed ensiled pulp are sufficient to meet the requirements of lactating cows and beef cattle.

In several experiments pulp residues have been demonstrated to be similar in nutritive value to the whole crop in terms of digestibility of OM and DM and conversion of DM to liveweight gain (MAQUIRE and BROOKS 1973, VARTHA et al. 1973, JONES et al. 1974, HOUSEMAN et al. 1975, CONNELL and FOXELL 1976). In those experiments the pulp residues were fed to animals in fresh, ensiled and artificially dried form. GREENHALGH and REID (1975) suggested that some modifications occur in pulping and pressing which lead to improvement of pressed forage utilization.

The pulp residues obtained from grass or lucerne have been reported to ensile easily with relatively small effluent losses (JONES et al. 1974), although some workers (RAYMOND and HARRIS 1957, VARTHA et al. 1973) have reported difficulties in the ensiling process, due to the low sugar content of the pulp. The palatability of ensiled pressed crops has been noted to be relatively good (JONES et al. 1974, HOUSEMAN et al. 1975). Pressed lucerne silage fed to dairy cows had the characteristics of the conventional wilted whole crop (CONNELL and FOXELL 1976). Attention has been drawn to the substantial reduction in field dry matter losses through the avoidance of field wilting.

Table 5 shows the composition of the juice extracted from grass, red clover and pea in 1979 and 1980, giving the mean values and ranges. 
Table 4. Composition and in vitro digestibility of forage (A) and pulped pressed forage (B) (as \% of DM)

\begin{tabular}{|c|c|c|c|c|c|c|c|c|}
\hline Crop & DM & Ash & $\begin{array}{l}\text { Crude } \\
\text { protein }\end{array}$ & $\begin{array}{l}\text { True } \\
\text { protein }\end{array}$ & $\begin{array}{l}\text { Crude } \\
\text { fibre }\end{array}$ & $\begin{array}{l}\text { Water soluble } \\
\text { carbohydrates }\end{array}$ & $\begin{array}{l}\text { Pepsin } \mathrm{HCl} \\
\text { soluble } \\
\text { protein }\end{array}$ & $\begin{array}{l}\text { In vitro } \\
\text { DOMD }\end{array}$ \\
\hline Grass $1 \mathrm{~A}$ & 21.1 & 9.5 & 15.3 & 11.8 & 28.2 & 7.1 & 78.8 & 68.5 \\
\hline B & 32.9 & 6.5 & 16.3 & 12.7 & 31.1 & 5.3 & 74.8 & 64.5 \\
\hline Grass $2 \mathrm{~A}$ & 12.7 & 10.4 & 19.0 & 13.8 & 26.2 & 2.4 & 73.2 & 66.0 \\
\hline B & 31.8 & 6.6 & 19.1 & 16.1 & 31.1 & 2.1 & 68.3 & 60.9 \\
\hline Grass $3 \mathrm{~A}$ & 19.0 & 7.9 & 22.8 & 17.8 & 19.8 & 15.0 & 81.3 & 82.1 \\
\hline B & 33.2 & 5.5 & 23.1 & 20.0 & 22.8 & 10.4 & 77.7 & 79.9 \\
\hline Grass $4 \mathrm{~A}$ & 18.5 & 9.4 & 23.3 & 17.8 & 24.0 & 7.4 & 80.0 & 73.9 \\
\hline B & 35.3 & 5.8 & 22.0 & 19.5 & 28.5 & 4.7 & 74.2 & 70.1 \\
\hline Clover $1 \mathrm{~A}$ & 16.1 & 10.8 & 20.3 & 15.9 & 17.6 & 7.2 & 83.1 & 73.0 \\
\hline B & 27.1 & 7.6 & 19.4 & 16.8 & 22.9 & 4.1 & 74.3 & 67.1 \\
\hline Clover 2 A & 18.0 & 11.5 & 19.2 & 16.4 & 17.3 & 9.3 & 74.7 & 69.7 \\
\hline B & 28.6 & 7.8 & 22.6 & 18.8 & 22.9 & 5.4 & 75.8 & 70.1 \\
\hline Clover $4 \mathrm{~A}$ & 15.0 & 10.8 & 20.3 & 16.6 & 18.8 & 9.5 & 33.0 & 75.1 \\
\hline B & 29.0 & 7.2 & 19.7 & 17.6 & 25.5 & 4.9 & 74.6 & 69.6 \\
\hline Clover 5 A & 17.0 & 10.6 & 17.7 & 14.5 & 20.2 & 10.5 & 83.9 & 72.6 \\
\hline B & 32.2 & 6.7 & 16.7 & 14.7 & 28.0 & 5.0 & 73.8 & 66.9 \\
\hline Clover $6 \mathrm{~A}$ & 17.0 & 8.9 & 15.7 & 13.4 & 24.1 & 12.2 & 80.3 & 70.1 \\
\hline B & 33.7 & 5.9 & 15.7 & 13.5 & 30.0 & 6.2 & 70.4 & 64.7 \\
\hline Pea & 11.7 & 13.9 & 28.8 & 12.5 & 25.4 & 4.3 & 86.7 & 70.5 \\
\hline B & 15.9 & 12.2 & 19.3 & 11.8 & 29.3 & 4.0 & 81.6 & 67.0 \\
\hline $\begin{array}{l}\text { Whole crop } \\
\text { mean }\end{array}$ & 16.5 & 10.4 & 19.8 & 15.0 & 22.0 & 8.2 & 80.8 & 72.6 \\
\hline $\begin{array}{l}\text { Pressed crop } \\
\text { Mean }\end{array}$ & 30.4 & 7.1 & 19.4 & 16.2 & 27.3 & 5.0 & 74.3 & 67.5 \\
\hline
\end{tabular}

Expressed as percentages of DM, the levels of crude protein, ash and watersoluble carbohydrates are relatively high. The composition varied fairly widely between the different growth stages. The clover juices had higher means than the grass juices for DM, CP ja TP, but lower values for ash and water-soluble carbohydrates. The pea juice contained considerably more $\mathrm{CP}$ in DM than the other juices. The ratio of true protein to crude protein in the juices averaged $37.2 \%$ for grass, $59.6 \%$ for clover and $46.6 \%$ for pea.

The protein content of grass juice was low compared with the values reported from the literature (HOUSEMAN and CONNELL 1976, CHEESEMAN 1977, HOUSEMAN and JONES 1978). This suggests that the cells were ruptured less frequently during maceration, because the protein extracted from juice originates from intracellular fluid (PIRIE 1978). The amount of protein extracted also depends on the DM content of the forage (JONES and HOUSEMAN 1975) and the pressure applied (KOHLHEB 1978). In more mature grasses the high ratio of fibre to protein lowers the protein extractability (JONES and HOUSEMAN 1975).

Grass and lucerne juice has been fed to growing pigs in a number of trials (JONES and HOUSEMAN 1975, BRAUDE et al. 1977, BARBER et al. 1981), and its nutritive value has veen shown to be high. In pigs of 40 to $60 \mathrm{~kg}$ nitrogen 
Table 5. Composition of plant juice extracted from various crops.

\begin{tabular}{|c|c|c|c|c|c|c|c|c|c|}
\hline \multirow[t]{2}{*}{ Juice } & \multirow{2}{*}{$\begin{array}{c}\text { DM } \\
\%\end{array}$} & \multicolumn{2}{|c|}{ Ash } & \multicolumn{2}{|c|}{ Crude protein } & \multicolumn{2}{|c|}{ True protein } & \multicolumn{2}{|c|}{$\begin{array}{l}\text { Water soluble } \\
\text { carbohydrates }\end{array}$} \\
\hline & & $\%$ & $\%$ of DM & $\%$ & $\%$ of DM & $\%$ & $\%$ of DM & $\%$ & $\%$ of DM \\
\hline Grass 1 & 7.34 & 1.77 & 24.1 & 1.34 & 19.0 & 0.59 & 8.1 & 2.92 & 39.8 \\
\hline Grass 2 & 3.45 & 1.00 & 29.0 & 0.68 & 19.6 & 0.34 & 9.8 & 0.65 & 18.9 \\
\hline Grass 3 & 6.85 & 1.35 & 19.7 & 1.27 & 18.5 & 0.40 & 5.8 & 3.18 & 46.4 \\
\hline Grass 4 & 5.30 & 1.42 & 26.8 & 1.26 & 23.8 & 0.31 & 5.9 & 1.70 & 32.0 \\
\hline Clover 1 & 7.24 & 1.44 & 19.9 & 1.27 & 17.5 & 0.86 & 11.8 & 1.69 & 23.3 \\
\hline Clover 2 & 7.72 & 1.78 & 23.1 & 1.40 & 18.3 & 0.74 & 9.7 & 1.75 & 22.7 \\
\hline Clover 3 & 7.41 & 1.55 & 20.9 & 1.60 & 21.6 & 0.94 & 12.7 & 1.87 & 25.3 \\
\hline Clover 4 & 6.98 & 1.34 & 19.2 & 1.58 & 22.6 & 0.91 & 13.0 & 2.00 & 28.6 \\
\hline Clover 5 & 7.89 & 1.53 & 19.4 & 1.68 & 21.3 & 1.04 & 13.2 & 2.26 & 28.7 \\
\hline Clover 6 & 7.14 & 1.30 & 18.2 & 1.26 & 17.7 & 0.74 & 10.4 & 2.51 & 35.1 \\
\hline Pea & 4.56 & 0.94 & 20.6 & 1.69 & 37.1 & 0.79 & 17.3 & 1.29 & 28.3 \\
\hline Overall mean & 6.53 & 1.40 & 21.9 & 1.37 & 21.5 & 0.71 & 10.7 & 1.98 & 29.9 \\
\hline Grass mean & 5.74 & 1.39 & 24.9 & 1.14 & 20.2 & 0.41 & 7.4 & 2.11 & 34.3 \\
\hline Clover mean & 7.40 & 1.49 & 20.1 & 1.47 & 19.8 & 0.87 & 11.8 & 2.01 & 27.3 \\
\hline
\end{tabular}

retention was equally good when juice was substituted for fish meal as a supplement for barley (JONES and HOUSEMAN 1975). Similarly, partial to total replacement of fish meal or soybean meal with fresh or preserved juice from grass or lucerne did not affect performance and green crop juice supplied a substantial amount of protein (JONES 1977). In other trials, performance was similar when lucerne juice replaced $3.5 \%$ fish meal for pigs of 54 to $90 \mathrm{~kg}$, but was poorer when it replaced $7 \%$ fishmeal in diets for smaller pigs (BARBER et al. 1979). BRAUDE et al. (1977) also reported poorer performance when fish meal was replaced completely by lucerne juice. The drop in performance has been attributed to sub-clinical effects of excessive mineral levels in the lucerne juice (BARBER et al. 1981).

In the present study the potassium content of grass and clover was $8 \mathrm{~g} / \mathrm{kg}$ juice. Clover juice had twice as much calcium as grass juice but only half as much phosphorus (Table 9).

The composition and nutritive value of the leaf protein, concentrates precipitated from plant juice by heating or by combined heating and acidification are presented in Table 6. This fraction contains the insoluble cell constituents, such as chloroplasts, together with heat-denatured cytoplasmic protein. It is therefore enriched in protein and poor in soluble material compared with the forage from which it is derived. The dry matter content of LPC was rather low, on average $12.7 \%$, when it was separated with fourfold cheesecloth. The crude protein content of the leaf protein samples was high, on average $43.6 \%$ of DM, and the true protein content was also high, 38.5 $\%$. In LPC of clover the contents of CP and TP were $3 \%$ units higher than in grass LPC. Coagulation by heating gave about $2 \%$ units higher $\mathrm{CP}$ and TP contents than precipitation heating and acidification. In some samples the 
Table 6. Composition and in vitro digestibility of leaf protein concentrates from various crops (as \% of DM).

\begin{tabular}{|c|c|c|c|c|c|c|c|c|c|c|}
\hline Leaf protein & DM & Ash & $\begin{array}{l}\text { Crude } \\
\text { protein }\end{array}$ & $\begin{array}{l}\text { True } \\
\text { protein }\end{array}$ & $\begin{array}{l}\text { Crude } \\
\text { fibre }\end{array}$ & $\begin{array}{l}\text { Ether } \\
\text { extract }\end{array}$ & NFE & $\begin{array}{l}\text { Water soluble } \\
\text { carbohydrates }\end{array}$ & $\begin{array}{c}\text { Pepsin } \mathrm{HCl} \\
\text { soluble } \\
\text { protein }\end{array}$ & $\begin{array}{l}\text { In vitro } \\
\text { DOMD }\end{array}$ \\
\hline Grass 1 & 12.5 & 20.0 & 36.7 & 29.7 & 0.9 & 1.2 & 41.2 & 13.9 & 97.1 & 88.7 \\
\hline Grass 2 & 9.7 & 14.5 & 42.5 & 38.2 & 7.7 & 2.6 & 32.7 & 0.7 & 71.9 & 65.1 \\
\hline $\mathrm{HCl}$ prec. & 8.9 & 11.0 & 41.3 & 35.8 & 6.6 & 2.7 & 38.4 & 4.4 & 56.5 & 70.6 \\
\hline Grass 3 & 15.1 & 16.6 & 43.5 & 40.0 & 3.0 & 0.5 & 36.4 & 8.2 & 97.3 & 88.1 \\
\hline Grass 4 & 13.1 & 17.1 & 38.4 & 33.1 & 7.6 & 0.6 & 36.3 & 5.5 & 95.9 & 71.1 \\
\hline Clover 1 & 12.8 & 10.2 & 44.7 & 40.7 & 4.6 & 0.8 & 40.0 & 7.7 & 93.1 & 82.9 \\
\hline Clover 2 & 12.6 & 15.1 & 37.5 & 32.0 & 1.8 & 0.7 & 45.0 & 1.0 & 81.3 & 81.1 \\
\hline $\mathrm{HCl}$ prec. & 12.1 & 14.1 & 35.8 & 30.1 & 1.9 & 1.4 & 46.9 & 6.3 & 68.0 & 82.2 \\
\hline Clover 3 & 12.7 & 11.1 & 45.3 & 41.8 & 4.4 & 0.8 & 38.4 & 2.6 & 91.5 & 82.6 \\
\hline $\mathrm{HCl}$ prec. & 13.1 & 10.6 & 41.2 & 38.9 & 2.9 & 0.9 & 44.4 & 8.8 & 90.3 & 83.4 \\
\hline Clover 4 & 12.2 & 10.0 & 48.3 & 43.6 & 2.9 & 0.9 & 37.9 & 1.7 & 90.0 & 82.6 \\
\hline Clover 5 & 14.2 & 10.1 & 46.3 & 41.9 & 6.2 & 0.8 & 36.6 & 4.4 & 92.5 & 82.9 \\
\hline $\mathrm{HCl}$ prec. & 14.0 & 9.4 & 41.2 & 38.4 & 4.6 & 0.6 & 44.3 & 10.3 & 88.0 & 84.6 \\
\hline Clover 6 & 14.2 & 8.7 & 44.3 & 41.2 & 5.3 & 0.9 & 40.8 & 7.9 & 88.0 & 82.3 \\
\hline $\mathrm{HCl}$ prec. & 12.7 & 9.4 & 36.8 & 33.5 & 1.9 & 0.5 & 51.4 & 15.7 & 79.0 & 84.3 \\
\hline Pea & 12.4 & 12.6 & 59.2 & 49.9 & 9.0 & 0.8 & 18.5 & 1.0 & 88.6 & 75.2 \\
\hline $\mathrm{HCl}$ prec. & 13.8 & 17.4 & 58.8 & 46.2 & 8.1 & 1.0 & 20.7 & 1.6 & 85.5 & 76.4 \\
\hline Overall mean & 12.7 & 12.8 & 43.6 & 38.5 & 4.7 & 1.0 & 38.2 & 5.9 & 85.6 & 80.2 \\
\hline Grass mean & 11.9 & 15.8 & 40.5 & 35.4 & 5.2 & 1.5 & 37.0 & 6.5 & 83.7 & 76.7 \\
\hline Clover mean & 13.1 & 10.9 & 42.1 & 38.2 & 3.7 & 0.8 & 42.6 & 6.6 & 86.2 & 82.9 \\
\hline Heat precipit. & 12.9 & 13.3 & 44.2 & 39.3 & 4.9 & 1.0 & 36.7 & 5.0 & 89.7 & 80.2 \\
\hline Heat $+\mathrm{HCl}$ prec. & 12.4 & 12.0 & 42.5 & 37.2 & 4.3 & 1.2 & 41.0 & 7.7 & 77.9 & 80.3 \\
\hline
\end{tabular}

crude fibre content was rather high, $8-9 \%$ of DM, due to contamination of the plant juice during processing.

According to the in vitro digestibilities, the nutritive value of the LPC products was high. The pepsin-HCl-solubility of the crude protein of LPC averaged $85.6 \%$. Heat coagulation gave better solubilities than the combination of heating and acidification $(89.7 \%$ vs. $77.9 \%)$. Clover had slightly higher values than grass. In vitro organic matter digestibility averaged 80.2 $\%$. Digestion in vitro was $6.2 \%$ units higher for clover LPC than grass LPC, but did not differ between the two precipitation methods.

The amino acid composition of the LPC samples is presented in Table 8. The mean lysine content was $4.1 \mathrm{~g} / 16 \mathrm{~g} \mathrm{~N}$ and it decreased a little during the growing season. The methionine content averaged $1.6 \mathrm{~g} / 16 \mathrm{~g} \mathrm{~N}$ and threonine $3.8 \mathrm{~g}$. There were only small differences between grass and clover. The amino acid composition of leaf protein has been found to be remarkably independent of the age and species of the crop from which the LPC is derived (GERLOFF et al. 1965, BYERS 1971).

In feeding monogastric animals, the true protein and amino acid content is important. GERLOFF et al. (1965) and HOVE et al. (1974) reported that the limiting amino acid in LPC prepared from several species of crops was methionine, and that the other essential amino acids were present in amounts 
Table 7. Composition of deproteinized juice.

\begin{tabular}{|c|c|c|c|c|c|c|c|c|c|}
\hline \multirow[t]{2}{*}{ Treatments } & \multirow{2}{*}{$\begin{array}{c}\mathrm{DM} \\
\%\end{array}$} & \multicolumn{2}{|c|}{ Ash } & \multicolumn{2}{|c|}{ Crude protein } & \multicolumn{2}{|c|}{ True protein } & \multicolumn{2}{|c|}{$\begin{array}{l}\text { Water soluble } \\
\text { carbohydrates }\end{array}$} \\
\hline & & $\%$ & $\%$ of DM & $\%$ & $\%$ of DM & $\%$ & $\%$ of DM & $\%$ & $\%$ of DM \\
\hline Grass (5) mean & 4.42 & 1.22 & 28.5 & 0.76 & 17.2 & 0.22 & 4.7 & 1.46 & 30.2 \\
\hline Clover $(10)$ mean & 5.87 & 1.43 & 24.3 & 0.76 & 12.9 & 0.21 & 3.6 & 1.66 & 28.4 \\
\hline Heat prec. (12) & 5.32 & 1.35 & 25.7 & 0.76 & 14.5 & 0.23 & 4.4 & 1.59 & 29.4 \\
\hline Heat + HClprec.(5) & 5.14 & 1.28 & 25.5 & 0.80 & 17.1 & 0.18 & 3.5 & 1.49 & 28.2 \\
\hline Overall mean (17) & 5.06 & 1.27 & 25.6 & 0.76 & 16.3 & 0.21 & 3.7 & 1.48 & 28.1 \\
\hline
\end{tabular}

Table 8. Amino acid composition of leaf protein concentrates from various crops $(\mathrm{g} / 6 \mathrm{~g} \mathrm{~N})$.

\begin{tabular}{|c|c|c|c|c|c|c|c|c|c|c|c|c|c|c|c|}
\hline \multirow[t]{2}{*}{ Amino acid } & \multicolumn{5}{|c|}{ Grass } & \multicolumn{7}{|c|}{ Clover } & \multirow[t]{2}{*}{ Pea } & \multirow{2}{*}{$\begin{array}{l}\text { Ove- } \\
\text { rall } \\
\text { mean }\end{array}$} & \multirow[b]{2}{*}{ s.d } \\
\hline & 1 & 2 & 3 & 4 & Mean & 1 & 2 & 3 & 4 & 5 & 6 & Mean & & & \\
\hline Alanine & 5.3 & 6.3 & 7.8 & 6.9 & 6.6 & 6.0 & 6.0 & 6.0 & 4.7 & 5.4 & 5.6 & 5.6 & 6.2 & 6.0 & 0.8 \\
\hline Arginine & 3.1 & 5.8 & 2.5 & 3.6 & 3.8 & 8.2 & 7.9 & 1.7 & 3.3 & 1.0 & 4.0 & 4.4 & 7.3 & 4.4 & 2.5 \\
\hline Aspartic acid & 8.1 & 9.1 & 7.0 & 6.9 & 7.8 & 5.5 & 3.0 & 7.0 & 6.2 & 7.6 & 9.3 & 6.4 & 3.6 & 6.7 & 2.0 \\
\hline Glutamic acid & 8.8 & 9.8 & 8.7 & 9.3 & 9.2 & 9.2 & 9.0 & 7.5 & 6.5 & 9.8 & 10.4 & 8.7 & 9.8 & 9.0 & 1.1 \\
\hline Clycine & 3.7 & 6.0 & 6.1 & 4.4 & 5.1 & 5.2 & 5.7 & 5.2 & 3.2 & 3.7 & 4.9 & 4.7 & 4.0 & 4.7 & 1.0 \\
\hline Isoleucine & 3.6 & 5.0 & 3.2 & 3.3 & 3.8 & 4.0 & 3.9 & 3.3 & 3.5 & 4.3 & 4.9 & 4.0 & 3.0 & 3.8 & 0.7 \\
\hline Leucine & 6.4 & 9.0 & 7.4 & 7.1 & 7.5 & 8.1 & 7.8 & 7.0 & 5.8 & 7.7 & 8.2 & 7.4 & 7.2 & 7.4 & 0.9 \\
\hline Lysine & 3.4 & 4.5 & 5.4 & 3.4 & 4.2 & 4.3 & 4.9 & 4.4 & 3.5 & 3.3 & 3.8 & 4.0 & 4.4 & 4.1 & 0.7 \\
\hline Methionine & 1.3 & 1.7 & 2.3 & 1.8 & 1.8 & 1.7 & 1.2 & 1.8 & 1.2 & 1.4 & 1.1 & 1.4 & 1.8 & 1.6 & 0.4 \\
\hline Phenylalanine & 4.0 & 5.5 & 4.4 & 4.4 & 4.6 & 5.0 & 4.7 & 4.2 & 3.5 & 5.2 & 5.2 & 4.6 & 5.2 & 4.7 & 0.6 \\
\hline Proline & 4.8 & 5.4 & 5.0 & 4.6 & 4.9 & 4.6 & 5.7 & 5.0 & 3.5 & 4.5 & 4.9 & 4.7 & 3.9 & 4.7 & 0.6 \\
\hline Serine & 3.3 & 4.7 & 3.9 & 3.6 & 3.9 & 3.7 & 4.0 & 3.5 & 3.1 & 3.7 & 3.9 & 3.7 & 3.4 & 3.7 & 0.4 \\
\hline Threonine & 3.8 & 4.6 & 3.1 & 3.7 & 3.8 & 4.1 & 3.7 & 3.2 & 3.6 & 4.2 & 4.4 & 3.9 & 3.2 & 3.8 & 0.5 \\
\hline Tyrosine & 3.9 & 5.0 & 3.8 & 4.0 & 4.2 & 4.5 & 4.6 & 3.5 & 3.1 & 4.8 & 1.3 & 3.6 & 4.8 & 3.9 & 1.1 \\
\hline Valine & 5.0 & 6.4 & 4.5 & 4.7 & 5.2 & 5.6 & 5.0 & 4.5 & 4.9 & 5.5 & 5.7 & 5.2 & 3.9 & 5.1 & 0.7 \\
\hline
\end{tabular}

usually associated with highquality protein. The availability of lysine and methionine was judged to be high (CONNELL and FOXELL 1976).

The biological value and true digestibility of LPC obtained from various green crops were found to be very high when it was prepared under optimal conditions. The drying method and temperature were found to be crucial for the nutritive value (HOUSEMAN and CONNELL 1976, MORRIS 1977, HOUSEMAN and JONES 1978, PIRIE 1978).

High quality leaf protein is a valuable feed for pigs and poultry. Enriched with methionine, it can be used as the sole protein supplement in cereal diets. LPC has replaced fish meal in rations for growing pigs without adverse effects on performance, at least with pigs over $55 \mathrm{~kg}$ (DUCKWORTH et al. 1961, CARR and PEARSON 1976) and given good results as a substitute for soybean meal (CHEEKE 1975). In diets for laying hens LPC has value as a source of pigment (YOSHIDA and HOSHII 1981); its xanthophyll content is high. LPC levels of $20 \%$ in layers'diet (MORRIS 1977) and up to $54 \%$ in 
Table 9. Mineral composition of juice and leaf protein concentrate.

\begin{tabular}{|c|c|c|c|c|c|c|c|c|c|}
\hline \multirow{3}{*}{ Element } & \multicolumn{6}{|c|}{ Juice } & \multicolumn{3}{|c|}{ LPC } \\
\hline & \multicolumn{2}{|r|}{ Grass } & \multicolumn{2}{|c|}{ Clover } & \multicolumn{2}{|c|}{ Overall mean } & Grass & Clover & Overall mean \\
\hline & fresh & DM & fresh & DM & fresh & DM & & DM & \\
\hline $\mathrm{P} \mathrm{g} / \mathrm{kg}$ & 0.57 & 10.1 & 0.29 & 3.9 & 0.38 & 6.2 & 10,66 & 2.64 & 5.05 \\
\hline $\mathrm{Ca} \mathrm{g} / \mathrm{kg}$ & 0.78 & 14.3 & 1.68 & 22.6 & 1.27 & 19.0 & 22.07 & 12.92 & 16.29 \\
\hline $\mathrm{Mg} \mathrm{g} / \mathrm{kg}$ & 0.20 & 3.6 & 0.35 & 4.7 & 0.27 & 4.1 & 2.86 & 3.02 & 2.92 \\
\hline $\mathrm{K} \mathrm{g} / \mathrm{kg}$ & 8.79 & 153.4 & 8.15 & 110.0 & 7.93 & 121.9 & 45.90 & 33.58 & 36.86 \\
\hline $\mathrm{Na} \mathrm{mg} / \mathrm{kg}$ & 29 & 494 & 58 & 785 & 43 & 643 & 120 & 230 & 200 \\
\hline $\mathrm{Fe} \mathrm{mg} / \mathrm{kg}$ & 4 & 68 & 4 & 51 & 4 & 62 & 466 & 236 & 343 \\
\hline $\mathrm{Cu} \mathrm{mg} / \mathrm{kg}$ & 2 & 37 & 3 & 34 & 2 & 333 & 152 & 69 & 95 \\
\hline $\mathrm{Zn} \mathrm{mg/kg}$ & 4 & 74 & 8 & 110 & 7 & 107 & 207 & 118 & 161 \\
\hline $\mathrm{Mn} \mathrm{mg} / \mathrm{kg}$ & 4 & 71 & 5 & 59 & 4 & 58 & 376 & 51 & 149 \\
\hline
\end{tabular}

broiler diets (KUZMICKY and KOHLER 1977) have been used without adverse effects. Growth-depressing substances, such as saponins have been recognised in extracted juice and LPC, but these are partly removed in the deproteinized juice during the preparation of LPC.

\section{Conclusions}

Mechanical fractionation of green crops provides a means of extracting larger quantities of protein for utilization by nonruminants, leaving pulp suitable for ruminant livestock. Mechanical extraction of leaf protein is technically and probably commercially feasible and many systems are being developed for recovery of protein from forages and other leafy materials (WILKINS 1977, PIRIE 1978). At the industrial and commercial level, efforts are being directed to producing leaf protein concentrate and drying pulp residues for green meal. On the farms, systems of green fractionation can be operated to provide plant juice for feeding pigs and processed residues for ruminants. Recent research has indicated the technical potential of green crop fractionation for improving grassland production and utilization. The nutritive values of grass juice, pressed pulp residues and leaf protein concentrate are promising. Further experimentation is necessary to identify the optimal methods of mechanical processing and to evaluate the economic aspects of fractionation.

Acknowledgements. Thanks are due to Mr. Timo Laitinen for technical assistance and to Ms. Lea Huida, M. Sc, Agricultural Research Centre, for the amino acid determinations. 


\section{References}

BARBER, S. R., BRAUDE, R., MITCHELL, K. G., PARTRIDGE, I. G. \& PITTMAN, R. J. 1979. Value of lucerne juice and grass juice as sources of protein for the growing pig. Anim. Feed Sci. Technol. 4: 233-262.

— , BRAUDE, R., MITCHELl, K. G., PARTRIDGE, I. G. \& PITTMAN, R. J. 1980. Value of freshly produced lucerne juice as a source of supplemental protein for the growing pig. Anim. 'Feed Sci. Technol. 5: 215-220

- , BRAUDE, R., MITCHELL, K. G. \& PARTRIDGE, I. G. 1981. Lucerne juice as a protein supplement for growing pigs: effects of mineral content of the diet and of the water supply. Anim. Feed Sci. Technol. 6: 35-41.

BRAUDE, R., JONES, A. S. \& HOUSEMAN, R. A. 1977. The utilization of the juice extracted from green crops. Occ. Sym. Br. Grassl. Soc. No 9: 47-55. Harrogate.

BYERS, M. 1971. Amino acid composition and in vitro digestibility of some protein fractions from three species of leaves of various ages. J. Sci. Food. Agric. 22: 242-251.

CARR, J. R. \& PEARSON, G. 1976. Photosensitisation, growth performance and carcass measurements of pigs fed diets containing commercially prepared lucerne leaf-protein concentrate. N. Z. J. Exp. Agric. 4: 45-50.

CHEEKE, P. R. 1975. Nutritional evaluation of alfalfa protein concentrate with rats, swine and rabbits. Proc. $12^{\text {th }}$ Technic. Alfalfa Conf. 76-79. USDA. Berkeley.

CHEESEMAN, G. C. 1977. The chemical composition of forage juice and its preservation. Occ. Sym. Br. Grassl. Soc. No 9: 39-46.

CONNELL, J. \& FOXELL, P. R. 1976. Green crop fractionation, the products and their utilization by cattle, pigs and poultry. Bienn. Rev. Natn. Inst. Res. Dairy 21: 21-41.

DUCKWORTH, J., HEPBURN, W. R. \& WOODHAM, A. A. 1961. Leaf protein concentrates. II. The value of a commercially dried product for newly-weaned pigs. J. Sci. Food Agric. 12: 16-20.

ETTALA, E. \& KOSSILA, V. 1980. Organic matter, mineral and nitrogen losses from fresh grass silage during ensiling. Ann. Agric. Fenn. 19: 9-20.

GERLOFF, E. D., LIMA, I. H. \& STAHMANN, M. A. 1965. Amino acid composition of leaf protein concentrates J. Agric. Food Chem. 13: 139-143.

GREENHALGH, J. F. D. \& REID, G. W. 1975. Mechanical processing of wet roughage. Proc. Nutr. Soc. $34: 74$.

HOUSEMAN, R. A. \& CONNELL, J. 1976. The utilization of the products of green-crop fractionation by pigs and ruminants. Proc. Nutr. Soc. 35: 213-220.

— \& JONES. 1978. Green crops and animal production. Vet. Rec. 102: 336-339.

HOVE, E. L., LOHREY, E., URS, M. K. \& ALLISON, R. M. 1974. The effect of lucerne-protein concentrate in the diet on growth, reproduction and body composition of rats. $\mathrm{Br}$. J. Nutr. 31: $147-157$.

JONES, A. S. 1977. The principles of green crop fractionation. Occ. Symp. Br. Grassl. Soc. No 9: 1-7.

- , HOUSEMAN, R. A. 1975. Forage crop fractionation. Rep. Rowett Inst. 31: 136-149.

- , MAC LEOD, N. A., MAC DEARMIND, A. \& HOUSEMAN, R. A. 1974. The value of grass pulp for ruminants. Proc. Br. Soc. Anim. Prod. 3: 113.

KOHLHEB, R. 1978. Gewinnung von Nährstoffkonzentraten aus grünen Planzen. Diss. Göttingen.

KUZMICKY, D. D. \& KOHLER, G. O. 1977. Nutritional value of alfalfa leaf protein concentrate (ProXan) for broilers. Poult. Sci. 56: 1510-1516.

MADSEN, A., MORTENSEN, H. P. \& MIKKELSEN, C. 1981. Lucerne piller af lucernesaft til slagtesvin. Stat. Husdyrbr. Medd. No 369.

MAQUIRE, M. F. \& BROOKERS, I. M. 1973. The effects of juice extraction on the composition and yield of grass crops for dehydration. Proc. $1^{\text {th }}$ Int. Cong. Green Crop Drying, p. 346. Oxford.

MORRIS, T. R. 1977. Leaf-protein concentrate for non-ruminant farm animals. Occ. Symp. Br. Grassl. Soc. No 9: 67-82.

NÄSI, M. 1983. Preservation of grass juice and wet leaf protein concentrate. J. Scient. Agric. Soc. Finl. 55: $000-000$.

- , HUIDA, L. 1982. Digestibility of amino acids in pig diets containing Eurolysine bacterial protein or Pekilo protein with special reference to a gas chromatographic method used in amino acid determination. J. Scient. Agric. Soc. Finl. 54: 279-285. 
OSTROWSKI, H. T. 1976. Pasture production in a protein extraction system. Proc. N. Z. Soc. Anim. Prod. 36: 30-41.

NØRRGAARD-PEDERSEN, E. J. N., WITT, N., MORTENSEN, J. \& SØRENSEN, C. 1980. Fraktionering af grømatogrøder ved udpresning af saft og konservering af pressede afgrøder og saft. Tidskr. Plantavl. 84: 265-293.

PIRIE, N. W. 1978. Leaf protein and other aspects of fodder fractionation. 169 p. Camb. Univ. Press. London.

RAYMOND, W. F. \& HARRIS, C. E. 1957. The value of the fibrous residue from leaf protein extraction as a feeding stuff for ruminants. J. Br. Grassl. Soc. 12: 166.

SALO, M. L. 1965. Determination of carbohydrate fractions in animal foods and faeces. Acta Ag1. Fenn. 105: 1-102.

SYRJÄLÄ, L., SETÄLÄ, J., PULLI, S., BOMAN, M. \& PUTKONEN, A. 1980.Vihanta herne säilörehun raaka-aineena. Koetoiminta ja käytäntö. 1. 7. 1980.

SYRJÄLÄ-QVIST, L., SETÄLÄ, J. \& KORTESMAA, H. 1982. Vihanta härkäpapu säilörehun raakaaineena. Koetoiminta ja käytäntö 11. 5. 1981.

TAUSSKY, H. H. \& SHORR, E. 1953. A microcolorimetric method for the determination of inorganic phosphorus. J. Biol. Chem. 202: 675-685.

TERRY, R. A., OSBOURN, D. F., CAMMEL, S. B. \& FENLON, J. S. 1974. In vitro digestibility and the estimation of energy in herbage. Proc. $5^{\text {th }}$ Cen. Meet. Eur. Grassl. Fed. p. 19-25. Uppsala.

TILLEY, J. M. \& TERRY, R. A. 1963. A two-stage technique for the in vitro determination of forage crops. J. Br. Grassl. Soc. 18: 104-111.

VARTHA, E. W., ALLISON, R. M. \& FLETCHER, L. R. 1973. Protein-extract herbage for sheep feeding. N. Z. J. Exp. Agric. 1: 171.

WILKINS, R. J. 1977. Green crop fractionation. Occ. Symp. Br. Grassl. Soc. No 9. Harrogate.

YOSHIDA, M. \& HOSHII, H. 1981. Leaf protein concentrates. Poult. Inst. Nov. 106-110.

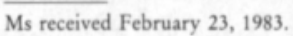

\section{SELOSTUS}

\section{Lehtiproteiinin eristäminen vihermassasta}

\section{Matti Näsi \\ Helsingin yliopisto, kotieläintieteen laitos}

Tutkimuksessa selvitettiin proteiinin eristämistä laidunruohosta ja palkokasveista sekä analysoitiin erotettujen tuotteiden kemiallista koostumusta ja rehuarvoa. Puristamalla saatu mehusaanto oli $55 \%$ vihermassan tuorepainosta. Kuiva-ainetta $(\mathrm{ka})$ ja raakavalkuaista (rv) erottui mehuun $22.6 \%$ ja $24.1 \%$. Saostamalla saatuun lehtiproteiinitiivisteeseen erottui mehun ka:sta $23.7 \%$, rv:sta $48.0 \%$ ja puhdasvalkuaisesta (pv) $80.7 \%$. Vihermassasta puristamisen jälkeen jääneen jätteen ka-pitoisuus lisääntyi $16.5 \%$ :sta $30.4 \%$ : :iin. Puristejätteen rv-pitoisuus oli $0.4 \%$-yksikköä alempi, raakakuitu $7.3 \%$ korkeampi ja in vitro -sulavuus $5.1 \%$ alempi kuin vastaavassa vihermassassa. Ruohomehun kuiva-ainepitoisuus oli $6.5 \%$ ja kuiva-aineesta oli $21.9 \%$ tuhkaa, $21.5 \%$ rv ja $10.7 \%$ pv sekä $29.9 \%$ sokereita. Apilahernemehujen rv-pitoisuudet olivat korkeampia kuin ruohomehussa. Lehti-proteiinitiiviste sisälsi keskimäärin $43.6 \%$ rv ja $38.5 \%$ pv ka:ssa. Lehtiproteiinin in vitro -sulavuus ja proteiinin pepsiini $\mathrm{HCl}$-liukoisuus oli keskimäärin $85.6 \%$ ja $80.2 \%$. Lehtiproteiinin lysiinipitoisuus oli $4.1 \mathrm{~g}$ ja metioniinipitoisuus $1.6 \mathrm{~g} / 16 \mathrm{~g} \mathrm{~N}$. Eri kasvilajeista ja eri kasvuasteissa tehtyjen lehtiproteiinitiivisteiden aminohappopitoisuuksissa oli vain vähäisiä eroja.

Lehtivalkuaisen eristäminen vihermassasta on teknisesti mahdollista ja sillä voitaisiin tehostaa nurmikasvien valkuaisen hyväksikäyttöä. Ruohomehun, lehtiproteiinitiivisteen ja puristejätteen koostumustietojen ja sulavuuksien perusteella niiden rehuarvot ovat hyviä. Lehtiproteiinituotannon taloudellisuus on selvitettävä erikseen. 